\title{
EUS-guided celiac plexus neurolysis/block
}

\author{
Narendra S. Choudhary, Rajesh Puri \\ Institute of Digestive and Hepatobiliary Sciences Medanta, The Medicity, Gurgaon, Haryana, India
}

\begin{abstract}
Refractory chronic abdominal pain as a result of inoperable pancreatic cancer or chronic pancreatitis poses a formidable challenge and can be effectively relieved with celiac axis block or celiac plexus neurolysis (CPN). Percutaneous celiac plexus block (CPB) or computed tomography (CT)-guidance using anterior or posterior approaches has some limitations. However, endoultrasound (EUS)-guided CPB has evolved itself as an effective and safe procedure for management of refractory abdominal pain. The EUS offers advantages, which include accurate anatomic imaging, real-time monitoring of injection, and anterior approach, which avoids neurologic complications. The CPN can be combined with staging and fine-needle aspiration cytology (FNAC) of a malignancy in the same session. The present review discusses anatomic details of celiac axis block, procedure-related details, complications, contraindications, comparison to other modalities, and results of various studies and author's experience of EUS guided $\mathrm{CPB} /$ neurolysis.

Key words Celiac plexus, computed tomography, endoscopic ultrasound, neurolysis
\end{abstract}

\section{Introduction}

In 1914, Max Kappis used splanchnic nerve blocks for surgical anesthesia. ${ }^{[1]}$ Initially, celiac plexus block (CPB) was performed using posterior approach that was associated with risk of neurological complications, and hence, was replaced by anterior approach. Currently, celiac axis block or neurolysis is used for management of refractory pain secondary to inoperable pancreatic cancer or chronic pancreatitis. ${ }^{[2-5]}$ The celiac plexus innervates the liver, gallbladder, biliary tract, pancreas, spleen, adrenal glands, kidneys, mesentery, and the small and large bowel proximal to the transverse colon. ${ }^{[2]} \mathrm{CPB}$ refers to temporary inhibition of the celiac plexus with the help of bupivacaine and corticosteroid injections in patients with benign pancreatic diseases such as chronic pancreatitis. Celiac plexus neurolysis (CPN) refers to the ablation of the plexus (chemical splanchnicectomy which ablates the afferent

\section{Access this article online}

\begin{tabular}{|l|c|}
\hline \multirow{2}{*}{$\begin{array}{l}\text { Website: } \\
\text { www.jdeonline.in }\end{array}$} & Quick Response Code \\
\hline DOI: & \\
10.4103/0976-5042.132394 & \\
\hline
\end{tabular}

nerve fibers that transmit pain from intra-abdominal viscera), and is often achieved with alcohol or phenol administered with a local anesthetic. ${ }^{[6]} \mathrm{CPN}$ using alcohol is not routinely used in benign diseases as there is risk of retroperitoneal fibrosis, which would render any subsequent pancreatic surgery more difficult. Anterior approach under computed tomography (CT)- or ultrasound-guidance has been used to avoid neurological complications. ${ }^{[7,8]}$ Endoultrasound (EUS)-guided celiac axis block/neurolysis has several advantages over other modalities. EUS uses anterior approach, thus, it avoids neurological complications and relative proximity of the celiac ganglia to the posterior gastric wall ensures an accurate passage of the needle into the ganglia, thereby minimizing the risk of complications and increasing effectiveness of block. ${ }^{[5,6]}$ Comparison of various celiac axis approaches is shown in Table 1.

\section{Anatomy of Celiac Plexus}

Celiac 'plexus' (ganglia and interconnecting fibers) is the largest plexus of sympathetic nervous system located in upper abdomen; it comprises of preganglionic sympathetic efferent nerve fibers derived from the greater splanchnic (T5-T9), lesser splanchnic (T10-T11), and least splanchnic (T12) nerves; preganglionic parasympathetic efferent fibers (from posterior trunk of the vagus nerve) and the visceral afferent fibers (for nociceptive stimuli) from the upper abdominal viscera. The 
celiac plexus innervates the liver, gallbladder, biliary tract, pancreas, spleen, adrenal glands, kidneys, mesentery, and the small and large bowel proximal to the transverse colon. The celiac plexus lies within retroperitoneal space posterior to the stomach and pancreas embedded in loose areolar tissue, close to the celiac axis anterolateral to aorta at the level of first lumbar vertebra, just inferior to origin of celiac artery as shown in Figure 1 and is separated from vertebral column by crus of diaphragm. ${ }^{[2,4,9-12]}$ There is considerable variability in size $(0.5-4.5 \mathrm{~cm})$, number (1-5), and position (T12-L1 disc space to middle of L2 - vertebral body). Zhang et al., reported that $94 \%$ of the celiac ganglia are located at the level of T12 or L1. ${ }^{[10]}$

\section{EUS-Guided CPB/CPN-Procedure}

The procedure is done under deep sedation. Patients on antiplatelet/anticoagulant drugs need to stop them to allow normalization of hemostasis. The patient is given intravenous fluids to prevent risk of hypotension that may arise from splanchnic blood pooling due to unopposed parasympathetic action after $\mathrm{CPB} /$ neurolysis. The procedure is performed with a curvilinear array EUS scope. The EUS under endoscopic view is passed into the proximal stomach, just distal to the gastroesophageal junction and along the posterior wall of the stomach, the aorta and the celiac axis (first vessel arising from the aorta below the diaphragm) are identified. ${ }^{[13,14]}$ The celiac plexus is identified as a hypoechoic, oblong, or lobulated structures, often with irregular edges, containing hyperechoic foci or strands, anterolateral to the origin of the celiac artery. ${ }^{[15-17]}$ After identification of base of celiac trunk, a EUSfine-needle aspiration (FNA) needle is passed through the biopsy channel and secured to the Luer-Lock assembly. This needle is advanced under real-time EUS imaging through the posterior wall of the stomach adjacent and anterior to the lateral aspect of the aorta at the level of celiac trunk origin. An aspiration test is done to rule out vessel puncture before injection. For neurolysis, 5-10 mL

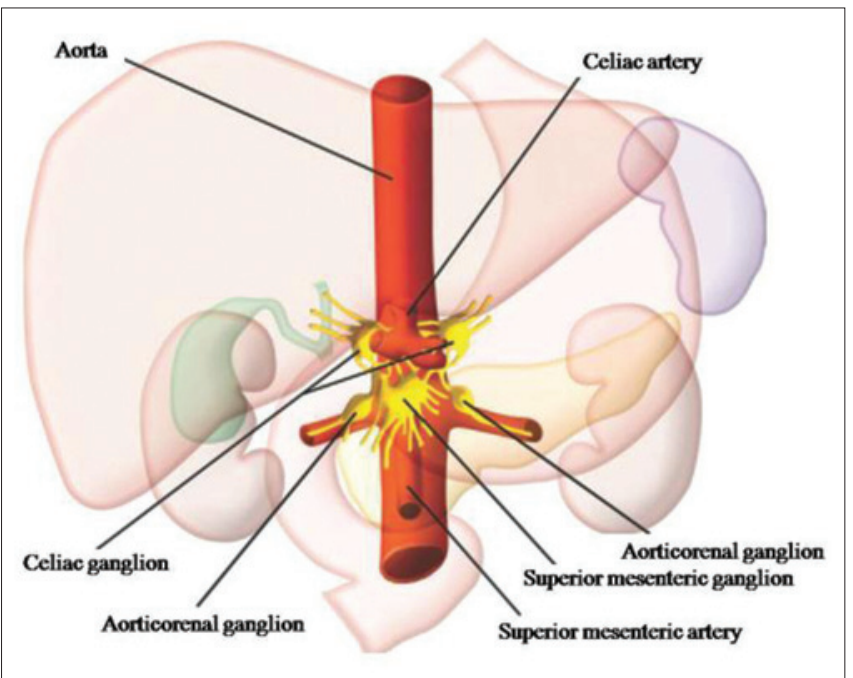

Figure 1: Morphologic and functional anatomy of the celiac plexus (adapted from reference 2) of a local analgesic bupivacaine $(0.25 \%)$ is injected followed by $10-20 \mathrm{~mL}$ of a neurolytic agent (98\% dehydrated ethanol), which will produce an echogenic cloud; for plexus blocks, $20 \mathrm{~mL}$ of $0.25 \%$ bupivacaine is injected followed by $80 \mathrm{mg}$ of triamcinolone. Alternatively, half amount may be injected to each side of celiac trunk. Our center uses EUS-FNA cytology (FNAC) needle having multiple side holes for CPN/CPB (Echotip; Cook Endoscopy, WinstonCook ${ }^{\mathrm{TM}}$ ); these multiple side holes ensure uniform distribution of neurolytic agents; however, there are no studies comparing one needle with another.

Contraindications of procedure ${ }^{[4,18]}$ are summarized in Table 2. Relative contraindications include altered anatomy interfering in obtaining adequate access or a history of multiple prior $\mathrm{CPBs}$ in patients with chronic pancreatitis. There are no guidelines regarding hemostasis for undertaking $\mathrm{CPB} / \mathrm{CPN}$, but at our center we follow same recommendations as outlined for EUS-guided FNAC. These include stopping all antiplatelet and anticoagulants except aspirin 7 days prior to the procedure

Table 1: Comparison of various techniques for celiac plexus block/neurolysis (adapted from reference 2)

\begin{tabular}{|c|c|c|}
\hline Technique & Advantages & Disadvantages \\
\hline Fluoroscopy & Easily available & $\begin{array}{l}\text { Anatomic details } \\
\text { are not seen } \\
\text { Radiations are } \\
\text { involved }\end{array}$ \\
\hline Ultrasonography & $\begin{array}{l}\text { Easily available } \\
\text { Vascular structures are } \\
\text { identifiable } \\
\text { Diffusion of neurolytic agent may } \\
\text { be seen without contrast medium }\end{array}$ & $\begin{array}{l}\text { Not good for } \\
\text { retro-peritoneum } \\
\text { Operator } \\
\text { dependent }\end{array}$ \\
\hline CT & $\begin{array}{l}\text { Retroperitoneal structures are } \\
\text { identifiable } \\
\text { May show celiac plexus } \\
\text { Shows exact location of the } \\
\text { needle tip and surrounding } \\
\text { structures } \\
\text { Shows diffusion of neurolytic } \\
\text { agents }\end{array}$ & $\begin{array}{l}\text { Radiations are } \\
\text { involved }\end{array}$ \\
\hline EUS & $\begin{array}{l}\text { Shows proximity to celiac plexus } \\
\text { Anatomic details well imaged } \\
\text { Real-time monitoring of } \\
\text { neurolytic injection } \\
\text { Anterior approach avoids } \\
\text { neurologic complications } \\
\text { Allows staging, FNAC and/or } \\
\text { biopsy }\end{array}$ & $\begin{array}{l}\text { Operator } \\
\text { dependent } \\
\text { Invasive } \\
\text { Snowstorm } \\
\text { effect may hinder } \\
\text { visualization of } \\
\text { the celiac plexus }\end{array}$ \\
\hline
\end{tabular}

$\mathrm{CT}=$ Computerized tomography, EUS=Endoultrasound, FNAC=Fine-needle aspiration cytology

Table 2: Contraindications of celiac plexus block or neurolysis

Patients with coagulopathy

Local/intra-abdominal infection and sepsis

Bowel obstruction

Patients on disulfiram therapy for alcohol abuse

Patients with physical dependence and drug seeking behavior

Thrombocytopenia (platelets $<50,000$ )

An uncooperative patient 
and to ensure a platelet count of $>50,000$ and international normalized ratio (INR) $<1.5 .{ }^{[19]}$

\section{Results of EUS-Guided CPB/CPN and Comparison to Other Modalities}

Table 3 summarizes the results of various studies using EUS-guided CPN/CPB and their comparison to CT- and fluoroscopic-guided CPN/CPB. ${ }^{[20-30]}$ In a systemic review of EUS-guided CPN of 17 studies for relief of pain; eight studies involved 283 patients of pancreatic cancer and nine studies with 376 patients of chronic pancreatitis. The review concluded that pain relief occurred in $80.12 \%$ ( $95 \%$ confidence interval $(\mathrm{CI})=74.47-85.22)$ and in $59.45 \%$ (95\% CI $=54.51-64.30)$ for pancreatic cancer and chronic pancreatitis, respectively. ${ }^{[31]}$ In general, EUS guided CPN/ $\mathrm{CPB}$ is safe and more effective than other modalities of $\mathrm{CPB}{ }^{[27,29]}$

A total of 62 patients underwent EUS-guided CPB/CPN at our center; of them 17 patients with chronic pancreatitis underwent $\mathrm{CPB}$ and 45 patients with pancreatic cancer and a few with gallbladder cancer underwent CPN for palliation of intractable pain. Eleven patients (17.7\%) had no improvement in pain. The narcotic requirement decreased in the remaining 51 patients $(82.3 \%)$ and relief lasted for 8-12 weeks in majority of these patients. There were no serious procedure-related complications in any of these patients.

\section{Complications}

In the posterior approach era, major complications were neurological such as monoplegia and anal and bladder sphincter dysfunction due to puncture of spinal artery resulting in spinal ischemia. Other complications included backache, pneumothorax, and retroperitoneal abscess. ${ }^{[2,7]}$ The common complications of EUS-guided celiac axis block/neurolysis are immediate pain, orthostatic hypotension (due to loss of sympathetic tone and splanchnic vasodilatation), and transient diarrhea. ${ }^{[14,18,32]}$ The potential risk of hypotension can be reduced by administering $500 \mathrm{ml}$ saline before the procedure and $500 \mathrm{ml}$ saline after procedure at a rate of $100 \mathrm{ml}$ per hour. A large series of 189 EUS-CPB and 31 EUS-CPN procedures which were performed in 128 and 30 patients, respectively, reported four complications (asymptomatic hypotension, retroperitoneal abscess, and severe self-limited pain in two patients). ${ }^{[33]}$ Uncommon complications of celiac plexus include chronic diarrhea, ${ }^{[34]}$ gastroparesis, ${ }^{[35]}$ retroperitoneal hemorrhage, peripancreatic abscess formation, ${ }^{[36]}$ and stomach rupture ${ }^{[37]}$ (after repeated injections).

\begin{tabular}{|c|c|c|c|}
\hline Author (year) & $N$, modality & Results & Comments \\
\hline $\begin{array}{l}\text { Wiechowska- } \\
\text { Kozłowska }^{[20]} 2012\end{array}$ & 29, CPN & $86 \%$ improved at $1-2$ weeks & Improvement of pain in $76 \%$ of patients after $2-3$ months \\
\hline $\begin{array}{l}\text { LeBlanc } \\
\text { et al.., }{ }^{[21]} 2011\end{array}$ & $\begin{array}{l}29 \text { in } 1 \text { injection and } 21 \\
\text { in } 2 \text { injections, CPN }\end{array}$ & $74 \%$ (69 vs $81 \%, P=\mathrm{NS})$ & $\begin{array}{l}\text { Median duration of pain relief in the } 1 \text {-injection and 2-injection } \\
\text { groups: } 11 \text { and } 14 \text { weeks ( } P=N S)\end{array}$ \\
\hline \multirow[t]{2}{*}{$\begin{array}{l}\text { Ascunce } \\
\text { et al., }{ }^{[22]} 2011\end{array}$} & $64, \mathrm{CPN}$ & $50 \%$ at 1 week & $\begin{array}{l}\text { Visualization of celiac ganglia was best predictor of } \\
\text { response (odds ratio 15.7; } P<0.001 \text { ) }\end{array}$ \\
\hline & & & $\begin{array}{l}\text { Tumors located outside the head of the pancreas and higher } \\
\text { baseline pain level were weakly associated with a good response }\end{array}$ \\
\hline $\begin{array}{l}\text { Wyse } \\
\text { et al.,[23] } 2011\end{array}$ & $40 \mathrm{CPN}, 48$ analgesics & $\begin{array}{l}\text { EUS-CPN group had less } \\
\text { pain and narcotic requirement }\end{array}$ & Used CPN at diagnosis of inoperable pancreatic cancer \\
\hline $\begin{array}{l}\text { Iwata } \\
\text { et al., }{ }^{[24]} 2011\end{array}$ & 47, CPN & Pain relief $68.1 \%$ & $\begin{array}{l}\text { Multivariate analysis: Direct invasion of celiac plexus and } \\
\text { distribution of ethanol only on the left side of the celiac artery } \\
\text { were negative predictors }\end{array}$ \\
\hline $\begin{array}{l}\text { Gunaratnam } \\
\text { et al.., }{ }^{[25]} 2001\end{array}$ & $58, \mathrm{CPN}$ & $\begin{array}{l}78 \% \text { patients had decline in } \\
\text { pain scores }\end{array}$ & \\
\hline $\begin{array}{l}\text { Sakamoto } \\
\text { et al., }{ }^{[26]} 2010\end{array}$ & $\begin{array}{l}34 \text { CPN vs } 33 \text { broad } \\
\text { plexus neurolysis } \\
\text { (including SMA) }\end{array}$ & BPN superior for pain control & Better neurolytic spread in BPN group (as seen by CT) \\
\hline $\begin{array}{l}\text { Santosh } \\
\text { et al., }{ }^{[27]} 2009\end{array}$ & $\begin{array}{l}27 \text { CPB vs } 29 \\
\text { fluoroscopic-guided CPB }\end{array}$ & 70 vs $30 \%$ improvement & EUS-CPB more effective than fluoroscopic technique \\
\hline \multirow[t]{2}{*}{$\begin{array}{l}\text { Gress } \\
\text { et al., }{ }^{[28]} 2001\end{array}$} & 90, СРВ & $\begin{array}{l}55 \% \text { had improvement in pain } \\
\text { score }\end{array}$ & $\begin{array}{l}26 \% \text { had persistent benefit beyond } 12 \text { weeks, } 10 \% \text { had } \\
\text { persistent benefit at } 24 \text { weeks; less response in }<45 \text { years of age } \\
\text { or previous pancreatic surgery for chronic pancreatitis }\end{array}$ \\
\hline & & & EUS-guided block cost effective compared to CT-guided block \\
\hline $\begin{array}{l}\text { Gress } \\
\text { et al.,[29] } 1999\end{array}$ & $\begin{array}{l}18 \text { CPB } \\
\text { (10 EUS-guided) }\end{array}$ & $\begin{array}{l}50 \text { (EUS group) vs } 25 \% \\
\text { (CT group) }\end{array}$ & $\begin{array}{l}\text { EUS group less cost and more persistent benefit ( } 40 \% \text { at } 8 \text { week } \\
\text { and by } 30 \% \text { at } 24 \text { week) than CT group }\end{array}$ \\
\hline $\begin{array}{l}\text { Wiersema and } \\
\text { Wiersema, }{ }^{\left[{ }^{[0]}\right]} 1996\end{array}$ & $\begin{array}{l}30 \mathrm{CPN} \\
\text { ( } 25 \text { carcinoma } \\
\text { pancreas) }\end{array}$ & $\begin{array}{l}79-88 \% \text { of patients had } \\
\text { persistent improvement in } \\
\text { their pain score }\end{array}$ & Median follow-up 10 weeks \\
\hline
\end{tabular}

EUS=Endoultrasound, SMA=Superior mesenteric artery, NS=Not significant, BPN=Broad plexus neurolysis, $\mathrm{CT}=$ Computed tomography 


\section{Conclusions}

CPN should be considered in patients with upper abdominal cancer where pain is not adequately controlled with analgesics or significant opioid-induced side effects are present. ${ }^{[38]} \mathrm{CPB}$ is used to provide temporary relief in chronic pancreatitis patients with significant pain to decrease dose of narcotics. ${ }^{[39]}$ EUS-guided CPN is a safe and useful modality for relief of intractable pain in patients with inoperable pancreatic cancer and chronic pancreatitis.

\section{References}

1. Fujita Y, Sari A. Max Kappis and the celiac plexus block. Anesthesiology 1997;86:508.

2. Kambadakone A, Thabet A, Gervais DA, Mueller PR, Arellano RS. CT-guided celiac plexus neurolysis: A review of anatomy, indications, technique, and tips for successful treatment. Radiographics 2011;31:1599-621.

3. Erdine S. Celiac ganglion block. Agri 2005;17:14-22.

4. Jain P, Dutta A, Sood J. Coeliac plexus blockade and neurolysis: An overview. Indian J Anaesth 2006;50:169-77.

5. Michaels AJ, Draganov PV. Endoscopic ultrasonography guided celiac plexus neurolysis and celiac plexus block in the management of pain due to pancreatic cancer and chronic pancreatitis. World J Gastroenterol 2007; 13:3575-80.

6. Varadarajulu S, Wallace MB. Applications of endoscopic ultrasonography in pancreatic cancer. Cancer Control 2004;11:15-22.

7. Wang PJ, Shang MY, Qian Z, Shao CW, Wang JH, Zhao XH. CT-guided percutaneous neurolytic celiac plexus block technique. Abdom Imaging 2006;31:710-8

8. Caratozzolo M, Lirici MM, Consalvo M, Marzano F, Fumarola E, Angelini L. Ultrasound-guided alcoholization of celiac plexus for pain control in oncology. Surg Endosc 1997;11:239-44.

9. Ward EM, Rorie DK, Nauss LA, Bahn RC. The celiac ganglia in man: Normal anatomic variations. Anesth Analg 1979;58:461-5.

10. Zhang XM, Zhao QH, Zeng NL, Cai CP, Xie XG, Li CJ, et al. The celiac ganglia: Anatomic study using MRI in cadavers. AJR Am J Roentgenol 2006;186:1520-3.

11. Mercadante S, Nicosia F. Celiac plexus block: A reappraisal. Reg Anesth Pain Med 1998;23:37-48.

12. Loukas M, Klaassen Z, Merbs W, Tubbs RS, Gielecki J, Zurada A. A review of the thoracic splanchnic nerves and celiac ganglia. Clin Anat 2010;23:512-22.

13. Soweid AM, Azar C. Endoscopic ultrasound-guided celiac plexus neurolysis. World J Gastrointest Endosc 2010;2:228-31.

14. Hoffman BJ. EUS-guided celiac plexus block/neurolysis. Gastrointest Endosc 2002;56:S26-8.

15. Gerke H, Silva RG Jr, Shamoun D, Johnson CJ, Jensen CS. EUS characteristics of celiac ganglia with cytologic and histologic confirmation. Gastrointest Endosc 2006;64:35-9.

16. Ha TI, Kim GH, Kang DH, Song GA, Kim S, Lee JW. Detection of celiac ganglia with radial scanning endoscopic ultrasonography. Korean J Intern Med 2008;23:5-8

17. Gleeson FC, Levy MJ, Papachristou GI, Pelaez-Luna M, Rajan E, Clain JE, et al. Frequency of visualization of presumed celiac ganglia by endoscopic ultrasound. Endoscopy 2007;39:620-4.

18. Levy MJ, Wiersema MJ. EUS-guided celiac plexus neurolysis and celiac plexus block. Gastrointest Endosc 2003;57:923-30.

19. Murad F, Levy MJ, Topazian M. Indications, preparation, risks, and complications. In: Hawes RH, Fockens P, Varadarajulu S, editors. Endosonography. $2^{\text {nd }}$ ed. Philadelphia: Elsevier Saunders; 2011. p. 29-37.

20. Wiechowska-Kozłowska A, Boer K, Wójcicki M, Milkiewicz P. The efficacy and safety of endoscopic ultrasound-guided celiac plexus neurolysis for treatment of pain in patients with pancreatic cancer.
Gastroenterol Res Pract 2012;2012:503098.

21. LeBlanc JK, Al-Haddad M, McHenry L, Sherman S, Juan M, McGreevy K, et al. A prospective, randomized study of EUS-guided celiac plexus neurolysis for pancreatic cancer: One injection or two? Gastrointest Endosc 2011;74:1300-7.

22. Ascunce G, Ribeiro A, Reis I, Rocha-Lima C, Sleeman D, Merchan J, et al. EUS visualization and direct celiac ganglia neurolysis predicts better pain relief in patients with pancreatic malignancy (with video). Gastrointest Endosc 2011;73:267-74.

23. Wyse JM, Carone M, Paquin SC, Usatii M, Sahai AV. Randomized, double-blind, controlled trial of early endoscopic ultrasound-guided celiac plexus neurolysis to prevent pain progression in patients with newly diagnosed, painful, inoperable pancreatic cancer. J Clin Oncol 2011;29:3541-6.

24. Iwata K, Yasuda I, Enya M, Mukai T, Nakashima M, Doi S, et al. Predictive factors for pain relief after endoscopic ultrasound-guided celiac plexus neurolysis. Dig Endosc 2011;23:140-5.

25. Gunaratnam NT, Sarma AV, Norton ID, Wiersema MJ. A prospective study of EUS-guided celiac plexus neurolysis for pancreatic cancer pain. Gastrointest Endosc 2001;54:316-24.

26. Sakamoto H, Kitano M, Kamata K, Komaki T, Imai H, Chikugo T, et al. EUS-guided broad plexus neurolysis over the superior mesenteric artery using a 25-gauge needle. Am J Gastroenterol 2010;105:2599-606.

27. Santosh D, Lakhtakia S, Gupta R, Reddy DN, Rao GV, Tandan M, et al. Clinical trial: A randomized trial comparing fluoroscopy guided percutaneous technique vs. endoscopic ultrasound guided technique of coeliac plexus block for treatment of pain in chronic pancreatitis. Aliment Pharmacol Ther 2009;29:979-84.

28. Gress F, Schmitt C, Sherman S, Ciaccia D, Ikenberry S, Lehman G Endoscopic ultrasound-guided celiac plexus block for managing abdominal pain associated with chronic pancreatitis: A prospective single center experience. Am J Gastroenterol 2001;96:409-16.

29. Gress F, Schmitt C, Sherman S, Ikenberry S, Lehman G. A prospective randomized comparison of endoscopic ultrasound- and computed tomography-guided celiac plexus block for managing chronic pancreatitis pain. Am J Gastroenterol 1999;94:900-5.

30. Wiersema MJ, Wiersema LM. Endosonography-guided celiac plexus neurolysis. Gastrointest Endosc 1996;44:656-62.

31. Puli SR, Reddy JB, Bechtold ML, Antillon MR, Brugge WR. EUS-guided celiac plexus neurolysis for pain due to chronic pancreatitis or pancreatic cancer pain: A meta-analysis and systematic review. Dig Dis Sci 2009;54:2330-7.

32. Gunaratnam NT, Wong GY, Wiersema MJ. EUS-guided celiac plexus block for the management of pancreatic pain. Gastrointest Endosc 2000;52:S28-34

33. O'Toole TM, Schmulewitz N. Complication rates of EUS-guided celiac plexus blockade and neurolysis: Results of a large case series. Endoscopy 2009;41:593-7.

34. Gafanovich I, Shir Y, Tsvang E, Ben-Chetrit E. Chronic diarrhea-induced by celiac plexus block? J Clin Gastroenterol 1998;26:300-2.

35. Iftikhar S, Loftus EV Jr. Gastroparesis after celiac plexus block. Am J Gastroenterol 1998;93:2223-5.

36. Navarro-Martinez J, Montes A, Comps O, Sitges-Serra A. Retroperitoneal abscess after neurolytic celiac plexus block from the anterior approach. Reg Anesth Pain Med 2003;28:528-30.

37. Loeve US, Mortensen MB. Lethal necrosis and perforation of the stomach and the aorta after multiple EUS-guided celiac plexus neurolysis procedures in a patient with chronic pancreatitis. Gastrointest Endosc 2013;77:151-2.

38. Nagels W, Pease N, Bekkering G, Cools F, Dobbels P. Celiac plexus neurolysis for abdominal cancer pain: A systematic review. Pain Med 2013;14:1140-63.

39. Lieb JG $2^{\text {nd }}$, Forsmark CE. Review article: Pain and chronic pancreatitis Aliment Pharmacol Ther 2009;29:706-19.

How to cite this article: Choudhary NS, Puri R. EUS-guided celiac plexus neurolysis/block. J Dig Endosc 2013;4:99-102.

Source of Support: Nil, Conflict of Interest: None declared. 